\title{
SENGKEDANı BENTUK REKAYASA LINGKUNGAN UNTUK PERMUKIMAN DAN PERTANIAN
}

\section{SWALES: FOR SETTLEMENT OF ENGINEERING ENVIRONMENT AND AGRICULTURE}

\author{
Iwan Hermawan \\ Balai Arkeologi BandungJalan Raya Cinunuk Km 17 Cileunyi Bandung \\ Email: iwan1772@yahoo.com
}

\begin{abstract}
Abstrak
Tulisan ini bertujuan mendeskripsikan pemanfaatan sengkedan oleh masyarakat dalam merekayasa lahan miring untuk memenuhi kebutuhan akan lahan permukiman dan pertanian. Pemanfaatan sengkedan untuk rekayasa lahan miring oleh masyarakat Sunda sudah dilakukan sejak zaman dahulu dan terus berlanjut hingga saat ini. Teknologi tersebut hingga saat ini masih tetap aktual dalam upaya mengelola lahan miring agar dapat dimanfaatkan sebagai lahan permukiman, pertanian, dan keagamaan. Metode penulisan yang dipergunakan pada tulisan ini adalah deskriptif dengan pendekatan kualitatif. Penggunaan sengkedan sebagai upaya merekayasa lahan miring merupakan bentuk rekayasa lingkungan oleh masyarakat Sunda dengan tetap mempertahankan keseimbangan alam. Pemanfaatan bagian lereng untuk pemukiman dan pertanian diimbangi dengan mempertahankan bagian puncak sebagai kawasan hutan. Melalui upaya tersebut, daur hidrologi tetap terjaga keseimbangannya, karena ketika turun hujan air masih bisa menyerap ke dalam tanah dan keluar dari dinding teras melalui celah di antara batu. Proses pengelolaan lahan tersebut diwariskan secara turun temurun dari generasi ke generasi melalui berbagai ajaran adat dalam bentuk pamali, buyut, tabu atau pantang larang. Perubahan pemanfaatan lingkungan dilakukan dengan tanpa pengrusakan dan keseimbangan ekologi tetap dipertahankan.
\end{abstract}

Kata kunci: terasering, pantang larang, pemukiman.

\begin{abstract}
This paper aims to describe the use of swales by public in manipulating sloping land to meet the demand for land settlement and agriculture. Utilization of swales to sloping land engineering by the Sundanese community has been made since ancient times and continues to this day. The technology is still up to date in an effort to manage the sloping land that can be usedas a land settlement, agriculture, and religious. Writing method used in the study is descriptive qualitative approach. The use of swales is an effort to manipulate the manage slopes form of environmental engineering by the Sundanese community by maintaining the balance of nature. The use of the slope for settlements and agriculture is balanced by maintaining the top as a forest area. Through these efforts, the hydrological cycle is maintained balance, because when it rains the water can still absorb into the soil and out of the walls through the gap between the stone terraces. The land management processes passed down from generation to generation through a variety of traditional teachings in the form of taboos, great-grandfather, taboo or forbidden abstinence Change of use of the environment without damaging and ecological balance is maintained.
\end{abstract}

Keywords: terracing, abstinencebans, settlements. 


\section{A. PENDAHULUAN}

Tatar Sunda menurut sumber setempat meliputi bagian barat Pulau Jawa yang mula-mula (sampai akhir abad ke-16) batasnya sebelah timur adalah Ci Pamali (Kali Pemali, sekarang), tetapi kemudian batas itu pindah ke sebelah barat ke $\mathrm{Ci}$ Losari (Rosidi, dkk, 2000: 618). Menurut Tome' Pires, orang Portugis yang berkunjung ke Nusantara tahun 1513, pada waktu itu Kerajaan Sunda menempati wilayah yang disebut tanah Sunda. Tanah Sunda terpisah dari tanah Jawa dengan batasnya $\mathrm{Ci}$ Manuk. Dikatakan pula Cimanuk adalah kota pelabuhan yang terletak di muara sungai. Kota Pelabuhan itu merupakan bagian ujung timur wilayah Kerajaan Sunda. Kota Pelabuhan Cirebon yang terletak di sebelah timur Cimanuk dikatakan tidak termasuk wilayah Kerajaan Sunda. Sesudah Kerajaan Sunda runtuh (sekitar tahun 1579), wilayahnya terbagi atas Sumedanglarang, Banten, Cirebon, dan Galuh. Wilayah-wilayah tersebut masing-masing berdiri sendiri. Sumedanglarang dan Galuh kemudian menjadi satu wilayah kesatuan dengan nama Priangan. Bekas wilayah Kerajaan Sunda disebut tanah Sunda atau tatar Sunda atau Pasundan. Pada perkembangan berikutnya, Priangan dipandang sebagai pusat tanah Sunda atau pusat tatar Sunda (Ekadjati, 1995: 5-8). Sehingga, penyebutan orang Sunda diarahkan pada Orang Sunda Priangan (Harsojo, 2004:308).

Oleh masyarakat pesisir, seperti penduduk Cirebon, orang Sunda disebut sebagaiurang gunung, wong gunung, dan tiyang gunung(orang gunung), maksudnya adalah mereka yang tinggal di daerah pegunungan. Penyebutan orang gunung bagi orang Sunda kemungkinan besar muncul setelah adanya anggapan pusat tanah Sunda adalah Priangan. Wilayah Priangan merupakan daerah pegunungan dengan puncak-puncaknya yang tinggi. Pada waktu yang bersamaan, peranan orang Sunda di daerah pesisir sejak akhir abad ke-16 M., beralih ke daerah pegunungan atau pedalaman. (Ekadjati, 1995: 9). Secara geografis, Jawa Barat dibagi menjadi lima wilayah berdasarkan kondisi geomorfologi, yaitu: (1) Wilayah bagian utara Pulau Jawa yang merupakan daerah dataran rendah luas membentang dari dari Selat Sunda sampai Cirebon. Wilayah ini dikenal dengan sebutan zone Jakarta; (2) Wilayah pegunungan tengah atau zone Bogor; (3) Kubah dan Punggungan Bayah; (4) Wilayah depresi antarmontana atau dikenal juga dengan sebutan dataran Bandung; dan (5) Wilayah pegunungan selatan Jawa Barat yang membentang sepanjang pantai selatan dari Selat Sunda di Barat sampai Sagara Anakan di Timur (Bemmelen, 1949: 26).

Kondisi lingkungan alam yang ekstrim di bagian tengah dan selatan Jawa bagian barat mendorong masyarakat Sunda untuk menyesuaikan diri dengan lingkungan setempat. Penyesuaian diri dengan lingkungan tersebut dapat dilihat dari pola tata ruang kawasan permukiman. Mereka berupaya menjaga keseimbangan lingkungan, membangun dengan tidak merrusak dan menjaga perbandingan yang seimbang antara luas kawasan terbangun dengan kawasan lindung. Selain itu, bahan bangunan untuk membangun berbagai bangunan dilakukan dengan cara memanfaatkan bahan bangunan yang berasal dari lingkungan setempat (Hermawan, 2013: 49-52; 2011: 144).

Upaya untuk memenuhi kebutuhan akan lahan permukiman dan pertanian di kawasan dengan topografi perbukitan dan pegunungan dilakukan oleh masyarakat dengan dua cara, yaitu (1) memanfaatkan lahan apa adanya dengan tidak melakukan rekayasa atas kontur lahan miring, dan (2) melakukan perubahan atas kontur lahan hingga menjadi lahan dengan kontur datar yang siap dimanfaatkan untuk kepentingan permukiman dan pertanian.

Mereka yang memanfaatkan lahan miring dengan kondisi apa adanya, tanpa melakukan rekayasa, melakukan kegiatan pertanian dengan cara pertanian lahan kering (huma). Untuk mendirikan 
bangunan, mereka melakukan penyesuaian dengan cara menyesuaikan tinggi rendahnya tiang pancang bangunan dengan topografi lahan, sehingga tinggi tiap tiang penyangga bangunan akan berbeda. Sebaliknya, mereka yang melakukan rekayasa lahan melakukan perubahan kontur lahan miring menjadi datar dengan cara penggalian dan pengurukan hingga menghasilkan lahan datar bertanggatangga atau berteras-teras untuk permukiman dan pertanian.

Berdasarkan uraian tersebut, permasalahan yang diangkat pada tulisan ini berkenaan dengan sengkedan sebagai bentuk rekayasa lahan dengan topografi miring. Tujuan tulisan ini adalah mendeskripsikan upaya masyarakat Sunda dalam melakukan rekayasa lahan miring untuk memenuhi kebutuhan akan lahan permukiman dan pertanian.

Pemanfaatan lahan dengan tidak melakukan pengrusakan sudah dilakukan oleh masyarakat Sunda secara turun temurun dan melakukannya sebagai bentuk kepatuhan dan penghormatan pada leluhur. Proses pewarisan kepada generasi berikut dilakukan melalui berbagai pamali, buyut atau pantang larang. Tujuannya, agar lingkungan di mana mereka hidup, tumbuh, dan berkembang tidak rusak. Penjayaan pamali, buyut atau pantang larang di tengah masyarakat Sunda merupakan bentuk kontrol kebudayaan terhadap masyarakatnya dalam menjalani kehidupan sehari-hari.

Konsep tata ruang suatu masyarakat akan berkaitan dengan sistem religi mereka, terutama yang berkaitan dengan pandangan dunianya. Secara khusus, pandangan suatu masyarakat dapat terlihat dari kosmologi mereka. Menurut definisinya, kosmologi berarti pemahaman dasar tentang kosmos. Keyakinan tentang kosmos pada umumnya berkaitan erat dengan kepercayaan terhadap kekuatan adi-kodrati yang menguasai, mengendalikan, atau melandasinya. Oleh karena itu, dapat dipahami betapa pentingnya pemahaman dan penghayatan kosmos sebagai prasarat untuk mencapai kebahagiaan hidup batiniah manusia (Sedyawati, 1995 dikutip Permana, 2006: 13). Pada masyarakat Kampung Naga, aturan-aturan kehidupan masyarakatnya memiliki hubungan antara agama, kepercayaan dan kosmologi. Dengan kekuatan tersebut, sanksi-sanksi aturan agama dan adat yang berhubungan dengan permasalahan tata ruang lingkungan dan aturan bangunan sangat ditaati oleh masyarakat Kampung Naga. Berkenaan dengan pencapaian keseimbangan kehidupan, mereka memiliki tujuan kawilujengan (menjadi lebih baik) (Ismudiyanto, 1987: 81-82).

Permukiman tradisional dikembangkan dan dihuni atas dasar tradisi atau budaya bermukim tertentu. Menurut Oliver (19887,1997 dalam Harus dan Rusnandar, 2011:8), Rumah dan permukiman yang berkembang berdasarkan tradisi atau budaya bermukim tertentu berkembang atas dasar tradisi Vernakular. Permukiman tersebut mempunyai pola atau keteraturan khas yang berbeda dengan pola permukiman modern. Kondisi tersebut terjadi karena permukiman vernakuler merupakan bentuk ekspresi budaya masyarakat, sehingga tata dan aturannya diatur oleh adat istiadat yang dipegang oleh masyarakat tersebut. Pola permukiman tradisional biasanya memusat atau "mengutub" dengan titik pusat atau inti kawasannya merupakan tempat yang disakralkan atau disucikan. Tempat yang paling sakral ini biasanya dihuni oleh pendiri atau merupakan bangunan yang dikeramatkan atau disucikan. Semakin jauh dari inti, tingkat kesakralannya semakin berkurang dan di luar kawasan tersebut merupakan kawasan yang tidak sakral (Egenter, 1991 dalam Harun dan Rusnandar, 2011: 11). Pada permukiman masyarakat Sunda, inti atau pusat permukiman merupakan tempat yang disucikan atau dikeramatkan. Inti tersebut dikelilingi oleh rumah-rumah penduduk dan bangunan penunjang. Pada bagian luar permukiman (biasanya dibatasi oleh pagar 
atau batas alam seperti pohon atau tanaman lain) merupakan bagian yang tidak sakral. Pada bagian ini ditempatkan kandang ternak dan atau tempat untuk aktivitas mandi, cuci, dan kakus.

Pada Perkampungan masyarakat Kampung Naga di Kecamatan Salawu Kabupaten Tasikmalaya, bagian inti wilayah perkampungan adalah leuweung karamat (hutan keramat). Di dalam hutan tersebut dimakamkan leluhur masyarakat Kampung Naga, yaitu Eyang Dalem Singaparana (Hermawan, 2013: 27).

Ruang wilayah dan ruang kawasan dengan keanekaragaman ekosistemnya merupakan sumber daya alam bagi setiap makhluk, termasuk manusia. Tanah, air, udara, hutan dan lain-lain merupakan sumber daya alam pokok bagi kehidupan di muka bumi. Hilang atau berkurangnya ketersediaan sumber daya alam tersebut dapat menimbulkan dampak negatif yang besar bagi kehidupan. Melalui berbagai kearifan tradisional yang masih dianutnya, masyarakat tradisional berusaha untuk menjaga keseimbangan antara kehidupan manusia dengan alam. Filosofi leuweung dalam pemahaman masyarakat Baduy/ Kasepuhan menunjukkan bahwa manusia mempunyai kewajiban untuk menghormati dan memelihara alam. Leuweung (hutan) memiliki fungsi perlindungan yang hakiki dalam kesinambungan kehidupan manusia. Istilah leuweung titipan (hutan yang diamanatkan) atau disebut juga leuweung sirah cai (hutan mata air) menunjukkan bahwa hutan mampu mengelola sumber air secara alami (Sobirin, 2007: 104). Berkenaan dengan pengelolaan lingkungan, leluhur masyarakat Sunda mengamanatkan agar Gunung - Kaian; Gawir - Awian; Cinyusu - Rumateun; Sampalan - Kebonan; Pasir - Talunan; Dataran - Sawahan; Lebak - Caian; Legok - Balongan; Situ - Pulasaraeun; Lembur - Uruseun; Walungan - Ruwateun yang artinya Gunung - Tanami Pepohonan; Tebing - tanami bambu; Mataair - pelihara; tanah kosong - dibuat kebun; bukit-tanami pepohonan; Tanah datar-dijadikan sawah; lembah-alirkan air; cekungan - dibuat kolam; danau-pelihara; kampung- perlu diurus; sungai - perlu dijaga (Sobirin, 2007: 107).

Uraian tersebut menunjukkan bahwa potensi yang tersedia di alam adalah untuk dimanfaatkan bukan dieksploitasi. Alam dan lingkungan merupakan titipan untuk disampaikan kepada anak cucu, kita hanya diberi amanat untuk menjaganya dan menyampaikannya kepada mereka. Ajaran inilah yang mendorong masyarakat Sunda untuk memanfaatkan lingkungan alam dengan tidak melakukan pengrusakan. Kehidupan masyarakat yang menyesuaikan diri dengan alam dan lingkungan menunjukkan proses adaptasi yang berlangsung terus menerus, turun temurun dari generasi ke generasi ditujukan agar terhindar dari bencana. Hal ini sesuai dengan teori Posibilisme yang dikemukakan oleh Vidal de la Blache (1854-1918). Menurut teori tersebut, setiap individu memberi sejumlah kemungkinan (possibilities) berbeda bagi setiap tempat dan humansociety (masyarakat) yang menentukan kemungkinan-kemungkinan tersebut, karena manusia adalah "free agent" yang darinya segala sesuatu dapat dimungkinkan (Hermawan, 2009: 34-37).

\section{B. METODE PENELITIAN}

Berkenaan dengan permasalahan dan tujuan yang diajukan. metode penulisan yang dipergunakan adalah deskriptif bersifat kualitatif dengan pendekatan etnografi, karena "Etnografi merupakan pekerjaan mendeskripsikan kebudayaan" (Spradley, 2006:3). Pengumpulan data dilakukan melalui kajian pustaka, wawancara terbuka, dan Pengamatan lapangan (Spreadley, 2006; Goetz and Lecomte, 1984). Semua kegiatan pengumpulan data dilakukan penulis secara langsung dengan tujuan agar data yang terkumpul bersifat objektif dengan kata lain peneliti sebagai instrumen (Lincoln dan Guba, 1985:18). Hanya manusia sebagai instrumen yang dapat memahami makna interaksi antarmanusia, 
membaca gerak muka, menyelami perasaan dan nilai yang terkandung dalam ucapan atau perbuatan responden. Walaupun digunakan alat rekam atau kamera, peneliti tetap memegang peranan utama sebagai alat penelitian (Nasution, 1996:9). Sebagian data yang dipergunakan pada tulisan ini merupakan hasil penelitian penulis tentang Ruang pada Masyarakat Sunda, Kasus Kampung Naga yang dilaksanakan pada tahun 2013.

\section{HASIL DAN BAHASAN}

Secara geografis, Jawa Barat dibagi menjadi lima wilayah berdasarkan kondisi geomorfologi, yaitu: (1) Wilayah bagian utara Pulau Jawa yang merupakan daerah dataran rendah luas membentang dari Selat Sunda sampai Cirebon. Wilayah ini dikenal dengan sebutan zone Jakarta; (2) Wilayah pegunungan tengah atau zone Bogor; (3) Kubah dan Punggungan Bayah; (4) Wilayah depresi antarmontana atau dikenal juga dengan sebutan dataran Bandung; dan (5) Wilayah pegunungan selatan Jawa Barat yang membentang sepanjang pantai selatan dari Selat Sunda di Barat sampai Sagara Anakan di timur (Bemmelen, 1949: 26). Kondisi geologi Jawa Barat bagian selatan berupa batuan lepas yang berasal dari endapan piroklastika dengan topografi terjal merupakan dua faktor yang menonjol penyebab tanah longsor. Secara klimatologis, Tatar Sunda beriklim tropika basah dengan curah hujan tinggi, sehingga jika hujan turun di atas normal, maka kondisi rawan ini akan berubah menjadi kritis dan dapat menimbulkan tanah longsor. Secara alamiah, faktor penyebab tanah longsor meliputi morfologi permukaan bumi, penggunaan lahan, litologi, struktur geologi, curah hujan, dan kegempaan. Selain faktor alamiah, juga disebabkan oleh faktor aktivitas manusia yang memengaruhi suatu bentang alam, seperti kegiatan pertanian, pembebanan lereng, pemotongan lereng, dan penambangan (Mubekti dan Alhasanah, 2008: 122).
Kondisi lingkungan geografis Jawa Barat telah mendidik warganya untuk memanfaatkan alam dengan seksama, yaitu memanfaatkan dengan tidak merusak. Alam dimanfaatkan bukan dieksploitasi sehingga kelestariannya tetap terjaga dan dapat diwariskan kepada generasi berikut. Naskah Sanghyang Siksa Kandang Karesian menguraikan Mana kreta na bwana, mana hayu ikang jagat, kena twah ning janma kapahayu (Maka menjadi sentosa dunia, maka menjadi sejahtera kehidupan ini, karena perbuatan manusia yang serba baik) (Danasasmita, dkk.,1987: 90/115). Upaya untuk menjaga kelestarian alam juga tercermin dalam pikukuh (petunjuk/nasihatleluhur) masyarakat Baduy, yaitu

Gunung teumeunang dilebur; lebak teu beunang diruksak; larangan teu meunang dirempak; buyut teu meunang dirobah; lojor teu meunang dipotong; pondok teu meunang disambung; nu lain kudu dilainkeun; nu ulah kudu diulahkeun; nu enya kudu dienyakeun.

(gunung tidak boleh dihancurkan; lembah tidak boleh dirusak; larangan tidak boleh dilanggar; buyut tidak boleh diubah; Panjang tidak boleh dipotong; pendek tidak boleh disambung; yang bukan harus dianggap bukan; yang dilarang harus tetap dilarang; yang benar harus dibenarkan) (Garna, 1993:139).

Pada bagian terdahulu sudah diuraikan bahwa masyarakat tradisional Sunda dalam menjalani kehidupannya selalu berupaya untuk berdampingan dengan alam. Bagi mereka, alam bukan untuk dieksploitasi namun untuk dimanfaatkan sebagaimana mestinya karena hidup bukan di alam namun hidup bersama alam. Hal ini menunjukkan bahwa alam mempunyai kedudukan yang sama dengan manusia. Bencana yang ditimbulkan oleh alam merupakan dampak yang timbul karena manusia telah merusak keseimbangan di alam.

Lingkungan Tatar Sunda yang rawan akan bencana telah mengajarkan masyarakat penghuninya secara turun 
temurun untuk hidup bersama alam. Alam lingkungan dimanfaatkan dengan tidak merusak. Pemanfaatan lahan harus sesuai dengan peruntukannya agar tidak tertimpa bencana karena pada dasarnya bencana terjadi akibat kesalahan manusia dalam memanfaatkan alam.

Berkenaan dengan pemilihan lahan yang baik untuk kawasan permukiman, para leluhur Sunda sudah memiliki panduannya sehingga bisa terhindar dari bencana. Salah satu naskah kuna yang menguraikan tata cara pemilihan lahan baik untuk permukiman, adalah naskah Warugan Lemah yang isinya menguraikan jenis-jenis lahan baik dan buruk untuk permukiman. Menurut naskah dimaksud, jenis topografi lahan adalah: (1) Telaga Hangsa, yaitu topografi lahan condong ke kiri. Topografi jenis ini tergolong baik karena mendatangkan kasih sayang orang lain; (2) Banyu metu, yaitu topografi lahan condong ke belakang. Termasuk topografi ini kurang baik, karena menyebabkan kaneneh, "kesayangan, apa yang disayangi" tidak akan menjadi; (3) Purba Tapa, yaitu topografi lahan condong ke depan merupakan topografi kurang baik, karena senantiasa kehilangan simpati (rasa suka) orang lain; (4) Ambek Pataka, yaitu topografi lahan condong ke kanan. Lahan dengan topografi ini kurang baik karena menyebabkan orang lain menyakiti hati; (5) Tanah yang Ngalingga Manik, dapat diartikan sebagai topografi lahan yang membentuk puncak permata dengan permukiman di puncaknya. Lahan dengan topografi ini merupakan lahan yang baik untuk permukiman, karena penduduknya akan diperhatikan dewata; (6) Singha Purusa, yaitu topografi lahan memotong bukit (pasir), berada di antara puncak dan kaki bukit. Lahan dengan topografi ini merupakan lahan yang baik karena dapat mendatangkan kemenangan ketika perang; (7) Sri Madayung, merupakan lahan yang berada di antara dua aliran sungai yaitu sungai kecil di sebelah kiri dan sungai besar di sebelah kanan. Lahan jenis ini termasuk kurang baik, karena menyebabkan dimadu oleh perempuan; (8) Sumara Dadaya, yaitu lahan dengan topografi datar. Lahan ini "mungkin" sama dengan istilah topografi Sunda Galudra Ngupuk. Lahan dengan topografi ini merupakan lahan yang cukup baik bagi permukiman karena menyebabkan rama senantiasa datang berkunjung; (9) Luak Maturun, yaitu topografi lahan berceruk karena di tengah wilayah terdapat lembah merupakan lahan yang kurang baik untuk permukiman karena menjadikan penduduknya memperoleh banyak penderitaan; (10) Wilayah Melipat, termasuk topografi wilayah permukiman yang kurang baik karena menyebabkan berkurangnya kekayaan; (11) Tunggang Laya, yaitu topografi wilayah permukiman yang menghadap laut merupakan lahan kurang baik untuk permukiman karena dapat menyebabkan penduduknya mati tersambar petir; (12) Mrega Hideng, yaitu lahan bekas kuburan merupakan lahan yang kurang baik untuk permukiman karena mengakibatkan wilayahnya kurang memiliki wibawa; (13) Jagal Bahu, yaitu tanah yang menganga (terpisah) sehingga terdapat celah yang memisahkan wilayah permukiman merupakan topografi lahan yang kurang baik karena mengakibatkan wilayahnya kurang memiliki wibawa; (14) Talaga Kahudanan, yaitu wilayah permukiman membelah sungai merupakan lahan yang kurang baik, karena penduduknya dapat mati oleh senjata orang lain dalam peperangan; (15) Wilayah yang membelakangi bukit atau gunung merupakan lahan yang kurang baik untuk permukiman karena akan merusak hubungan keluarga; (16) Si Bareubeu, yaitu lahan yang berada di bawah aliran sungai (katunjang ku cai) merupakan lahan kurang baik untuk permukiman karena akan dihukum dewata; (17) Kampung yang dikelilingi oleh rumah, termasuk permukiman yang kurang baik karena penduduknya akan menjadi rakyat jelata; (18) Bekas tempat kotor (picarian) dikelilingi oleh rumah merupakan wilayah permukiman yang kurang baik karena akan 
mendatangkan kesusahan (Gunawan, 2010: 151-152).

Pemilihan lahan juga perlu dilakukan agar penghuninya memperoleh kebaikan. Adapun ciri-ciri lahan dimaksud, adalah: (1) Apabila bagian lahan di sebelah barat lebih tinggi dari sebelah timur, maka lahan dimaksud merupakan lahan yang baik untuk dijadikan pekarangan, karena dianggap memberi berkah kepada penghuninya. Sebaliknya jika lahan di bagian sebelah timur yang lebih tinggi, maka lahan tersebut jelek untuk dijadikan pekarangan, (2) Apabila lahan di sebelah selatan lebih tinggi dari pada sebelah utara dipercaya akan banyak memberikan berkah dan rezeki. Sebaliknya jika lahan sebelah utara yang lebih tinggi dibanding bagian selatan menandakan lahan yang jelek untuk halaman, (3) Lahan yang rata, ada baiknya dan ada jeleknya. Baik mendapat berkah, jeleknya tidak mendapat apa-apa, (4) Apabila lahan miring ke barat, warnanya putih, rasanya manis, baunya harum, akan memberi makna kepada penghuninya yaitu tidak akan kekurangan rezeki, (5) Apabila lahan warnanya merah, rasanya manis, baunya menyengat akan memberi kesenangan, sangat dihormati dan disukai banyak orang, (6) Apabila lahan warnanya hijau, rasanya manis pedas dan berbau, akan memberikan keselamatan kepada anak dan harta bendanya, dan (7) Apabila lahan warnanya hitam, baunya amis, lahan ini jangan dipergunakan untuk lahan hunian karena akan berdampak jelek kepada penghuninya (Harun dan Rusnandar, 2011: 21).

Uraian tersebut menunjukkan bahwa pemilihan lahan yang tepat untuk permukiman dilakukan oleh para leluhur masyarakat Sunda dan diwariskan kepada generasi berikut secara turun temurun kepada generasi berikut. Tepat memilih lahan sebagai tempat untuk mendirikan rumah atau kawasan permukiman dan bijak dalam mengelola atau memanfaatkan lingkungan akan memberikan dampak positif bagi manusia. Manusia akan aman dan tenteram karena terhindar dari berbagai bencana, khususnya bencana alam, serta terlindung dari berbagai kejahatan.

\section{Pengelolaan lahan oleh masyarakat Sunda}

Pada kalangan masyarakat Sunda

Buhun (lama) dikenal asas kesatuan tiga, yaitu Tritangtu. Azas ini mendasari berbagai aspek perikehidupan masyarakat Sunda, baik yang bersifat fisik maupun sosial, termasuk berhubungan dengan kekuasaan. Berkenaan dengan kekuasaan pada masyarakat tradisional Sunda, pembagian kekuasaannya yaitu Rama, Resi, dan Ratu. Secara kosmologi, ruang pada masyarakat Sunda dibagi menjadi tiga bagian dunia, yaitu dunia atas (Buana Nyungcung), dunia bawah (Buana Larang), dan dunia tengah (Buana Panca Tengah). Dunia atas bersifat perempuan, dunia bawah bersifat laki-laki, dan dunia tengah bersifat campuran. Pembagian ruang tersebut tampak pada pembagian ruang di bangunan, maupun pembagian ruang secara geografis atau kawasan.

Pembagian ruang bangunan dapat dipandang secara horizontal dan vertikal. Pembagian ruang horizontal, setiap rumah secara garis besar dibagi menjadi tiga, yaitu bagian depan (tepas), bagian tengah (tengah imah), kamar (pangkeng), dan dapur (pawon). Rumah bagian depan (tepas) merupakan daerah kekuasan lakilaki, bagian tengah dan kamar merupakan tempat bersama laki-laki dan perempuan, serta bagian dapur (pawon dan goah) merupakan kekuasaan perempuan. 


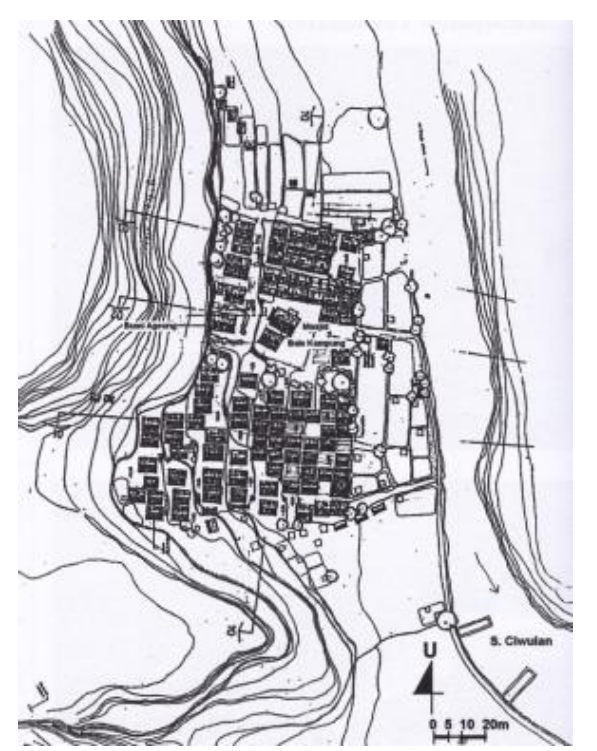

Gambar 1: Tata Ruang Kampung Naga

(Sumber: Harun dan Rusnandar, 2011: 90)

Secara vertikal, pembagian ruang bangunan dibagi menjadi tiga, yaitu kolong, lantai (palupuh), dan para. Lantai rumah merupakan gambaran dunia tengah (buana panca tengah) tempat hidup manusia, sehingga semua aktivitas manusia dilakukan di atas lantai rumah, termasuk kegiatan di dapur. Pada masyarakat tradisional Sunda, terutama masyarakat Baduy dan masyarakat Kampung Naga, dapur dibangun di atas lantai dengan tungku (hawu) diletakkan di lantai (palupuh) dapur bukan di permukaan tanah.

Pembagian ruang kawasan pada masyarakat Kampung Naga, adalah kawasan luar, kawasan permukiman, dan kawasan suci atau keramat. Antar kawasan dibatasi oleh pagar yang disebut pager jaga.
Tabel 1: Pembagian Ruang pada Masyarakat Kampung Naga

\begin{tabular}{ll}
\hline \multicolumn{2}{c}{ Pembagian Ruang } \\
\hline $\begin{array}{l}\text { Kosmografi Sunda } \\
\text { Buana Larang }\end{array}$ & Kampung Naga \\
$\begin{array}{ll}\text { (Dunia Bawah ) } \\
\text { Buana Pancatengah }\end{array}$ & Kawasan Permukiman \\
$\begin{array}{l}\text { (Dunia Tengah) } \\
\text { Buana Nyungcung } \\
\text { (Dunia Atas) }\end{array}$ & Hutan Keramat \\
\hline
\end{tabular}

Sumber: Hasil Penelitian, 2013

Pada penataan ruang secara kawasan tersirat pada azas Tritangtu, yaitu tata lampah, tata wayah, dan tata wilayah (Harun dan Rusnandar, 2011: 19). Berkenaan dengan tata wilayah, naskah Sunda kuna Sang Hyang Siksa Kandang Karesian menguraikan bahwa terdapat lahan yang tidak baik atau lahan kotor yang merupakan tempat raksasa, durgi, durga, kala, dan buta. Lahan tersebut, adalah: sodong, sarongge, cadas gantung, mungkal pategang, lebak, rancak, kebakan badak, catang nunggang, catang nonggeng, garunggungan, garenggengan, lemah sahar, dangdang warian, hunyur, lemah laki, pitunahan celeng, kalomberan, jaryan, kuburan, golongan tanah terbuang (Danasasmita,dkk., 1987: 11). Lahan-lahan tersebut merupakan lahan yang kurang baik untuk dijadikan kawasan permukiman karena merupakan lahan yang akan menimbulkan permasalahan atau bencana jika dijadikan permukiman. Jenis lahan tersebut dapat dimanfaatkan sebagai lahan pertanian jika dilakukan rekayasa atau pengelolaan lahan terlebih dahulu.

Pemanfaatan lahan untuk kepentingan permukiman dan pertanian sudah dilakukan oleh masyarakat dari dahulu dan terus dilakukan hingga saat ini. Masyarakat tradisional menggunakan pengetahuan mereka yang diperoleh secara turun temurun dari para leluhur. Keseimbangan alam secara tidak langsung selalu mereka perhatikan dalam mengelola alam dan lingkungan guna memenuhi kebutuhan hidup. Berbagai tabu, pamali, buyut, dan pantang larang lainnya tentang 
pengelolaan alam dan lingkungan dipatuhi masyarakat tanpa perlu mempertanyakan mengapa. Kondisi ini tetap berkembang dan terus dipertahankan oleh masyarakat tradisional Sunda dalam menjalani kehidupannya di muka bumi. Alam bagi mereka bukan untuk dieksploitasi, namun dimanfaatkan dengan tidak merusak.

Pemanfaatan lahan untuk berbagai kepentingan terus meningkat seiring dengan terus bertambahnya jumlah penduduk. Pemanfaatan lahan yang bijaksana, yaitu menjaga keseimbangan lingkungan akan menghindarkan manusia dari bencana. Masyarakat tradisional Sunda dalam memanfaatkan lingkungan selalu berupaya mengikuti petunjuk pemanfaatan lahan yang diwariskan leluhur. Semua itu dilakukan sebagai bentuk penghormatan kepada leluhur. Berdasarkan caranya, pemanfaatan lahan untuk permukiman dan pertanian oleh masyarakat tradisional Sunda dapat dikelompokkan menjadi dua, yaitu: (1) Pemanfaatan dengan tetap mempertahankan kontur permukaan tanah; dan (2) Pemanfaatan dengan mengubah kontur permukaan tanah.

Pertama, Pemanfaatan dengan tetap mempertahankan kontur permukaan tanah merupakan pemanfaatan lahan untuk kepentingan pertanian dan permukiman dengan tidak melakukan rekayasa terhadap lahan dengan topografi miring (terjal). Pemanfaatan lahan jenis ini masih dilakukan oleh masyarakat Baduy Dalam (Baduy Jero), yaitu di kampung Cikeusik, Cikartawana, dan Cibeo. Mereka masih memegang teguh buyut (pantang larang) warisan leluhur yang tergambar dalam pandangan hidup lojor teu meunang dipotong; pondok teu meunang disambung (panjang tidak boleh dipotong, pendek tidak boleh disambung). Hal ini menunjukkan bahwa dalam memanfaatkan alam dan lingkungan tidak boleh ada perubahan, karena perubahan walau sedikit akan menimbulkan kerusakan pada alam dan lingkungan.
Pada masyarakat Baduy Dalam, bangunan didirikan dengan menyesuaikan kondisi permukaan tanah, sehingga bangunan akan memiliki kaki/tiang bangunan yang berbeda tinggi karena menyesuaikan dengan kontur lahan. Selain itu, penggunaan paku untuk memperkuat sambungan tidak dibenarkan. Rangka bangunan diperkuat dengan menggunakan tali, biasanya tali ijuk, atau menggunakan pasak (lihat gambar 1). Untuk lahan pertanian pun mereka memperlakukan sama, yaitu tidak mengubah kontur permukaan tanah dan melakukan pengolahan tanah alakadarnya. Lahan bakal huma dibersihkan dari rumput dan tanaman perdu yang mengganggu. Sampah berupa potongan rumput dan tanaman perdu dibakar hingga habis dan yang tersisa hanya abu hasil pembakaran. Tahapan berikutnya, sisa pembakaran tersebut kemudian disebar secara merata ke seluruh bagian lahan yang akan ditanami. Setelah siap, Lahan tersebut kemudian ditanami oleh padi. Pada kondisi ini, rekayasa lahan tidak dilakukan untuk memperoleh permukaan lahan baru yang berbeda dengan sebelumnya.

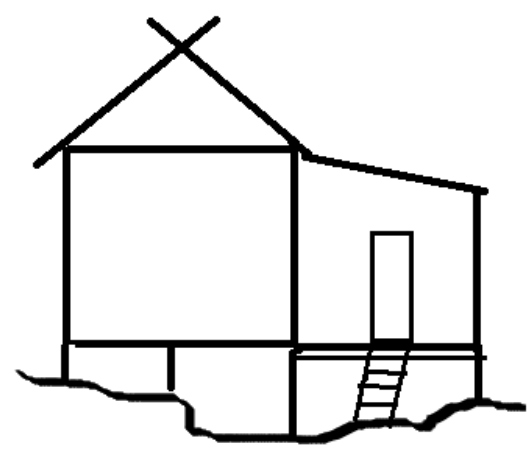

Gambar 1: Penampang rumah Baduy Dalam. Lahan untuk rumah di Baduy Dalam tidak diratakan, namun tiang/kaki rumah yang disesuaikan tinggi rendahnya

Kedua, Pemanfaatan lahan dengan cara merekayasa kontur lahan sebelum dimanfaatkan. Rekayasa kontur lahan 
dilakukan guna memperoleh lahan datar untuk kawasan permukiman atau pertanian. Untuk memperoleh lahan datar, maka lahan dengan kontur miring atau terjal dipangkas dan diurug, sehingga akan menghasilkan lahan datar yang bertingkat dengan dinding curam. Untuk memperkuatnya, terutama untuk kepentingan permukiman, dinding tanah diperkuat dengan susunan batu. Akibat lahan permukiman yang dihasilkan berteras maka bangunan yang didirikan akan memiliki perbedaan permukaan lahan sebagai, biasanya semakin tinggi posisi bangunan, jumlah bangunan yang bisa didirikan semakin sedikit karena lahan datar yang dihasilkan memiliki lebar yang sempit. sebaliknya pada lembah yang landai, banyak bangunan yang dapat didirikan, karena lahan datar yang dihasilkan lebih luas.

Pada bidang pertanian, lahan pesawahan di daerah pegunungan/ perbukitan merupakan contoh dari rekayasa lahan untuk pertanian. Setiap petak sawah memiliki lebar yang tidak sama antara di bagian landai dan di bangian puncak. Semakin puncak lebar sawah semakin sempit. Sisi panjang lahan sawah mengikuti bentuk kontur lahan tersebut. Sawah bertingkat banyak dijumpai di daerah perbukitan Jawa Barat.

Akibat kemiringan lahan yang ekstrim seringkali lahan datar tempat bangunan berdiri atau lahan pertanian mempunyai lebar sempit dan dinding yang terjal dan tinggi. Semakin terjal kemiringan lereng, semakin sempit lahan datar yang dihasilkan dan semakin tinggi dindingnya.

Pada permukiman masyarakat tradisional Sunda, tidak semua bagian bukit direkayasa untuk dijadikan sebagai lahan permukiman dan pertanian. Pada ketinggian tertentu sebelum puncak lahan miring tersebut akan dibiarkan dan dimanfaatkan sebagai kebun. Pada bagian puncak, biasanya tetap dipertahankan sebagai hutan dan dikeramatkan, seperti di kawasan masyarakat Baduy, hutan di puncak bukit tetap dipertahankan keberadaannya dan dijadikan sebagai hutan larangan yang dikeramatkan atau leuweung kolot (hutan tua). Kondisi serupa juga terjadi pada masyarakat Kampung Naga. Pada puncak bukit dimana permukiman masyarakat Kampung Naga berada, merupakan hutan keramat (leuweung karamat) Kampung Naga. Hutan tersebut merupakan hutan yang dikeramatkan karena di dalam hutan tersebut (di puncak bukit) dimakamkan leluhur Kampung Naga, yaitu Embah Dalem Eyang Singaparana.

Untuk memperkuat dinding sengkedan, dipergunakan batu yang berasal dari lingkungan sekitar permukiman. Pada sebagian perkampungan masyarakat Sunda, batu untuk memperkuat dinding tersebut diambil dari sungai yang mengalir di daerah tersebut. Batu-batu tersebut disusun hingga mampu menahan dinding sengkedan dari longsor. Pada punden berundak Gunung Padang, batu yang dipergunakan untuk membangun punden tersebut adalah balok-balok batu yang disusun sedemikian rupa sehingga membentuk dinding. Pada proses penyusunannya tidak dipergunakan semen sebagai pengikat atau penguat. Batu-batu tersebut disusun sedemikian rupa sehingga saling mengikat antara satu dengan yang lainnya. Kondisi tersebut menjadikan aliran air bawah permukaan tetap masih bisa mengalir di antara celah batu, tidak terhalang dan menumpuk sehingga memberi kekuatan yang tinggi pada dinding. Permukiman masyarakat Baduy Luar (Baduy Panamping), dan permukiman masyarakat Kampung Naga merupakan contoh bagaimana masyarakat tradisional Sunda melakukan rekayasa terhadap lahan miring dengan tidak merusak lingkungan. (lihat gambar2). 


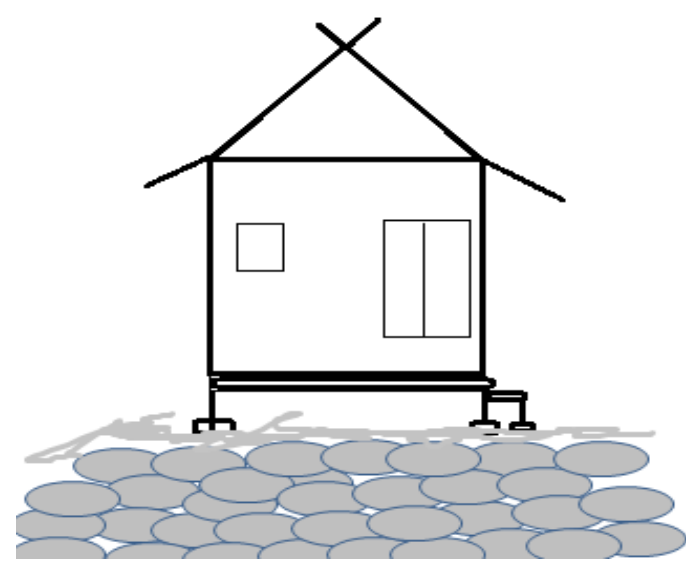

Gambar 2: Rumah Kampung Naga berdiri pada lahan yang datar dengan susunan batu sebagai penguat dinding teras

(Digambar oleh: Iwan Hermawan, 2015).

\section{Susunan Batu sebagai penguat lahan}

Rekayasa lahan untuk berbagai kepentingan dengan menggunakan media batu sebagai penguat lahan sudah dilakukan sejak dahulu oleh para leluhur masyarakat Sunda. Berbagai tinggalan arkeologi menunjukkan bagaimana proses adaptasi terhadap lingkungan dilakukan para leluhur. Mereka membangun kawasan permukiman dan membangun tempattempat pemujaan di puncak-puncak tinggi dengan memanfaatkan susunan batu sebagai penguatnya. Hal ini menunjukkan bagaimana para leluhur dengan pengetahuan dan keterampilannya menyesuaikan diri dengan lingkungan di mana mereka hidup. Gunung Padang di Desa Karyamukti Kecamatan Campaka Kabuapaten Cianjur Provinsi Jawa Barat merupakan salah satu bukti bagaimana masyarakat pendukung budaya Megalitik melakukan adaptasi dengan lingkungan sekitar. Mereka menyusun dan menata balok-balok batu di setiap bentuk bangunan hingga membentuk punden berundak Gunung Padang (Yondri, 2013: 164-165). Susunan batu tersebut berfungsi sebagai penahan teras dan bangunan yang berdiri di atasnya agar tidak longsor.

Penggunaan susunan batu untuk memperkuat lahan juga dilakukan pada nasa Kerajaan Sunda. Hal ini sesuai lengan isi prasasti Batutulis, yang serbunyi "....Beliaulah (Raja) yang nembuat tanda peringatan berupa gugunungan (bukit), ngabalai memperkeras jalan dengan susunan batu), nembuat hutan Samida, membuat Sanghyang Talaga Rena Mahawijaya" Danasasmita, 2003: 136). Selain itu, raskah Pantun Bogor mengungkapkan ddanya bale pamujan (Balai Pemujaan) yang digambarkan berupa punden serundak dengan teras-terasnya yang diperkeras oleh tatanan batu dan tanah (Munandar, 2008 dikutip Widyastuti, 2013: 126).

Seperti sudah diuraikan di atas, masyarakat tradisional di tatar Sunda masih memanfaatkan bongkahan atau butiran batu yang disusun sedemikian rupa untuk memperkuat dinding teras yang sengaja dibuat untuk kepentingan permukiman dan pertanian. Masyarakat Kampung Naga dan masyarakat Baduy Panamping merupakan kelompok masyarakat Sunda yang kawasan permukimannya berada di daerah perbukitan dengan batuan pembentuknya adalah batuan piroklastik gunung api. Kondisi geologi demikian menjadikan kawasan tersebut mudah tergerus ketika hujan turun.

Untuk memenuhi kebutuhan akan lahan permukiman, leluhur Kampung Naga melakukan rekayasa lahan dengan cara membuat sengkedan dengan dinding diperkuat tumpukan batu.

Untuk menghindarkan diri dari bahaya longsor yang mengancam serta tingginya erosi akibat kemiringan lereng yang curam serta curah hujan yang tinggi, leluhur masyarakat Kampung Naga membuat sengkedan (trap). Lahan hasil sengkedan tersebut kemudian diperkuat dengan batu-batu kali yang diambil dari sungai Ci Wulan. Tinggi antar teras berkisar 0,5 meter sampai 6 meter. Untuk menghubungkan teras yang lebih rendah dengan yang lebih tinggi dibuat tangga (Undakan) di pinggir lahan. Tangga 
tersebut dibentuk dari susunan batu yang menahan teras-teras lahan permukiman.Lahan Permukiman Kampung Naga yang bertingkat tersebut menjadikan kawasan Kampung Naga sebagai kawasan yang sehat karena setiap rumah memperoleh pencahayaan sinar matahari pagi yang baik. Selain itu, permukiman Kampung Naga yang bertingkat menjadikannya Kampung Naga tampak artistik.

Tidak berbeda dengan masyarakat Kampung Naga, masyarakat Baduy Panamping juga melakukan rekayasa lahan untuk memenuhi kebutuhan mereka akan lahan permukiman. Lahan miring kawasan permukiman mereka direkayasa hingga menghasilkan lahan datar bertanggatangga untuk permukiman. Sebagai penguat, dipergunakan susunan batu kali pada dinding teras tersebut. Susunan batu tersebut tidak diperkuat dengan semen karena dilarang secara adat (buyut).

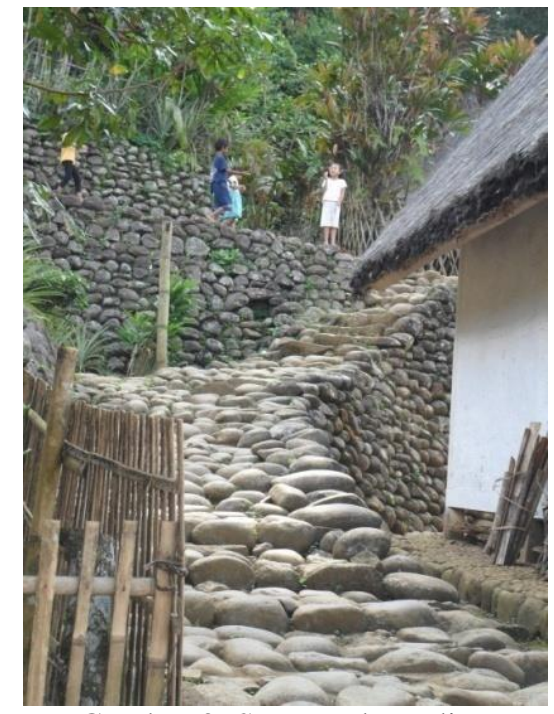

Gambar 3: Susunan batu di

Kampung Naga (Dokumentasi Iwan Hermawan, 2011)

Pemanfaatan batu dalam rekayasa permukaan tanah juga dilakukan agar halaman atau jalan tidak becek ketika turun hujan, kegiatan ini disebut Ngabalai. Biasanya batu yang dipergunakan untuk ngabalai adalah bongkah atau butir batu yang ukurannya relatif sama. Butiran batu tersebut disusun di atas permukaan tanah atau lantai hingga menjadi rata. Karena tidak menggunakan semen sebagai perekat antar batu, maka air masih bisa mengalir ke dalam tanah melalui celah-celah susunan batu-batu tersebut.

\section{Memanfaatkan dengan tanpa merusak}

Kebutuhan akan lahan
permukiman dan pertanian telah mendorong masyarakat Sunda untuk melakukan rekayasa atas lahan dimaksud. Rekayasa tersebut dilakukan dengan sedikit mungkin mengakibatkan ketidakseimbangan alam. Umpak batu merupakan salah satu bentuk rekayasa alam dengan tidak merusak, karena daur hidrologi bawah permukaan tanah tidak terganggu, air masih bisa mengalir di antara sela-sela batuan di dinding teras atau punden.

Lahan miring yang direkayasa menjadi teras-teras bertingkat dilakukan agar lahan tersebut dapat dimanfaatkan untuk permukiman dan pertanian. Proses tersebut dilakukan dengan mengubah lahan miring menjadi datar dalam bentuk teras bertingkat atau sengkedan atau terasering. Agar tidak terjadi longsor, dinding teras diperkuat dengan batu kali yang disusun sedemikian rupa sehingga mampu menahan bidang tanah di atasnya hingga tidak menimbulkan longsor. Susunan batu tersebut tidak diperkuat dengan tembok/cor yang dapat merekatkan satu batu dengan batu lainnya. Kondisi ini menjadikan terdapat ruang antar butiran batu sehingga air dapat tetap menerobos dan keluar di dinding teras. Kenyataan ini akan berbeda jika batu-batu tersebut direkatkan dengan adukan semen dan pasir, karena tatanan air bawah permukaan akan terganggu. Air akan bertumpuk di bawah tanah dan menekan dinding (turap) tebing. Jika tekanan itu makin besar akibat air yang terkandung dalam tanah serta tidak adanya celah antar batu maka dinding penahan tebing dapat bobol dan menimbulkan bencana bagi manusia. 
Rekayasa lingkungan yang dilakukan oleh masyarakat tradisional Sunda dilakukan dengan tidak merusak. Lahan yang dialihfungsikan menjadi kawasan permukiman, luasnya seimbang dengan luas lahan yang dibiarkan tetap sebagai hutan. Upaya melakukan rekayasa pada lingkungan dilakukan dengan tanpa merusak. Mereka menjaga keseimbangan alam dengan cara menjaga keseimbangan antara lahan terbangun dengan luas lahan yang tetap dibiarkan sebagai hutan. Masyarakat Kampung Naga yang tinggal di kawasan perbukitan Jawa Barat bagian tengah, mempertahankan luas perkampungan mereka dengan tidak melakukan ekspansi ke hutan yang berada di atasnya.

Pengetahuan dan keterampilan dalam mengelola alam tersebut diperoleh karena adaptasi masyarakat terhadap lingkungan di mana mereka hidup. Pengetahuan dan keterampilan hidup tersebut kemudian diturunkan dari generasi ke generasi melalui berbagai ajaran adat berupa buyut, pamali atau pantang larang. Kelangsungan ajaran leluhur dalam mengelola alam tersebut bisa tetap hidup di tengah masyarakat, karena mereka masih menjayakan dan mematuhi setiap ajaran leluhur. Semua itu dilakukan sebagai bentuk bakti dan penghormatan kepada leluhur. Berbagai pertanyaan berkenaan dengan kehidupan mereka dan pengelolaan oleh lingkungan akan selalu dijawab "kedah kieu saur karuhun ge, sieun matak lamun tambelar" (harus begini kata leluhur juga, takut ada bencana kalau melanggar) atau masyarakat Baduy akan menjawab "ceuk karuhun kudu kitu, teu wasa kami kudu ngarempag buyut" (kata leluhur juga harus begitu, saya tidak punya kuasa untuk melanggar aturan leluhur). Hal ini menunjukkan akan kuatnya kepercayaan masyarakat pada leluhurnya. Mereka percaya bahwa apa yang diajarkan oleh leluhurnya merupakan ajaran baik yang jika dilaksanakan akan membawa ke kehidupan lebih baik dan jika membangkang atas ajaran leluhur maka akan mendapat sanksi atau hukuman.

Kondisi alam tatar Sunda yang memiliki topografi terjal dengan curah hujan yang tinggi serta batuan pembentuknya merupakan material vulkanik merupakan kondisi lingkungan yang tidak ideal bagi permukiman, karena rawan bencana, terutama longsor. Hal inilah yang mendorong para leluhur masyarakat Sunda untuk berupaya hidup dengan menyesuaikan diri terhadap kondisi lingkungan. Pembuatan teras atau trap pada lahan miring yang diperkuat dengan susunan batu (umpak batu) guna memperoleh lahan datar untuk permukiman dan pertanian merupakan bentuk penyesuaian yang tidak merusak. Pemilihan batu kali sebagai bahan untuk memperkuat trap atau teras karena bahan yang disediakan oleh alam adalah batu.

Rekayasa bentang lahan yang dilakukan oleh masyarakat Sunda terhadap lahan miring untuk permukiman dan pertanian dengan cara membuat terasering yang diperkuat oleh susunan batu atau umpak batu menunjukkan bentuk penyesuaian manusia dengan alam. Hal ini sesuai dengan teori Posibilisme yang dikemukakan oleh Vidal de la Blace, bahwa alam telah menyediakan potensinya dan manusia menentukan pilihan untuk memanfaatkannya. Berkenaan dengan pemanfaatan sumber daya alam, leluhur masyarakat Sunda memberi amanat agar pengelolaan alam harus dilakukan secara bijak agar alam dan kekayaan di dalamnya masih dapat dinikmati anak cucu di kelak kemudian hari.

Agar lahan yang permukiman atau pertanian tidak hancur akibat ketidakseimbangan alam, maka perubahan atau rekayasa tersebut dilakukan secara bijaksana. Hanya sebagian kecil lahan yang diubah konturnya untuk kepentingan hajat hidup penghuninya, sebagian besar lahan dibiarkan tetap sebagai hutan dan dijaga kelestariannya. Masyarakat Kampung Naga membagi lahan adat mereka menjadi tiga, yaitu kawasan hutan, 
kawasan permukiman, dan kawasan luar. Kawasan hutan dimaksud adalah hutan keramat (leuweung karamat) dan hutan lindung (leuweung tutupan atau leuweung biuk). Pada kawasan ini masyarakat Kampung Naga tidak boleh memanfaatkan hasil hutan terutama kayu, walau hanya kayu bakar. Larangan tersebut hingga saat ini masih dipatuhi oleh masyarakat Kampung Naga dan tidak ada seorang pun yang berani melanggarnya karena takut akan sanksi leluhur atau kualat. Demikian pula pada masyarakat trandisional Sunda lainnya, pada masyarakat Baduy mereka mempertahankan hutan-hutan yang ada di puncak bukit (leuweung kolot) agar tidak diubah fungsinya menjadi kawasan perladangan. Pada masyarakat kampung juga demikian mereka memiliki hutan besar (leuweung gede) yang merupakan hutan lindung sekaligus hutan keramat yang tidak boleh dimanfaatkan hasilnya.

Uraian tersebut menunjukkan, keberadaan hutan bagi lingkungan masyarakat tradisional Sunda sangat penting bagi kondisi ekologi setempat, karena keberadaan hutan merupakan mata rantai lingkungan yang berperan terhadap iklim mikro sekaligus sebagai sumber kehidupan karena beraneka-ragamnya jenis tumbuhan dn hewan hidup di hutan tersebut. Jika mata rantai ini terputus, maka bencana mengancam sebagai akibat tidak seimbangnya alam lingkungan.

\section{PENUTUP}

Jawa Barat, terutama bagian tengah dan selatan merupakan daerah dengan kondisi lingkungan yang ekstrim, yaitu topografinya curam, batuan induk pembentuknya merupakan batuan piroklastik, dan curah hujan tinggi. Kondisi lingkungan tersebut telah mendidik masyarakatnya untuk hidup berdampingan dengan alam. Bentuk penyesuaian hidup terhadap alam salah satunya dilakukan dengan pembuatan teras-teras yang dindingnya diperkuat oleh susunan batu atau umpak batu.
Secara ekologis penggunaan umpak batu untuk memperkuat dinding terasering merupakan hal yang tepat karena tata air bawah permukaan. Air masih tetap mengalir ke luar dari sela-sela susunan batu. Kondisi ini tidak akan terjadi jika terasering tersebut dindingnya diperkuat oleh semen atau beton karena mengganggu tata air bawah tanah karena air tidak bisa ke luar dengan bebas dari sela susunan batu.

Pengetahuan pengelolaan dan pemanfaatan alam secara bijaksana (memanfaatkan dengan tidak merusak) yang diwariskan oleh para leluhur merupakan pengetahuan yang tetap perlu dipertahankan dan terus diwariskan kepada generasi muda melalui proses pendidikan, baik di sekolah, rumah, maupun lingkungan. Pengenalan kepada generasi berikut perlu dilakukan melalui proses penafsiran baru dari berbagai pamali, buyut, tabu atau pantang larang yang berkembang di tengah masyarakat tradisional. Jawaban mengapa pamali, tabu, buyut, tabu atau pantang larang tidak berhenti karena takut kutukan namun sampai kepada jawaban yang ilmiah dan dapat diterima secara Ilmu Pengetahuan.

\section{DAFTAR SUMBER}

\section{Jurnal, Makalah, Bunga Rampai}

Garna, Judhistira. 1993.

"Masyarakat Baduy di Banten."dalam Koentjaraningrat (Editor). Masyarakat Terasing di Indonesia. Jakarta: Gramedia. 120-152

Gunawan, Aditia. 2010.

"Warugan Lemah : Pola Pemukiman Sunda Kuna" dalam Perubahan Pandangan Aristokrat Sunda (Seri Sundalana). Bandung: Pusat Studi Sunda.

Hermawan, Iwan.2013. Ruang Pada Masyarakat Sunda, Kasus Kampung Naga. Laporan Penelitian Individual. Jakarta: Pusat Penelitian dan Penerbitan, Lembaga Penelitian dan 
Pengabdian kepada Masyarakat UIN Syarif Hidayatullah.

Hermawan, Iwan. "Pola Tata Ruang Permukiman Tradisional Sunda: Studi terhadap Permukiman Masyarakat Kampung Naga”. dalam Supratikno Rahardjo (Editor). Arkeologi: Pola Permukiman dan Lingkungan Hidup. Bandung: Alqaprint, 2011.

Ismudiyanto. "Kosmologi Perilaku Meruang di Kampung Naga, Telaah Singkat Pola Ruang Konsentris Kampung Naga di Desa Neglasari Kecamatan Salawu Kabupaten Tasikmalaya " dalam Media Teknik. No 2 Tahun IX April - Juni 1987.

Mubekti dan Fauziah Alhasanah. "Mitigasi Daerah Rawan Tanah Longsor Menggunakan Teknik Pemodelan Sistem Informasi Geografis: Studi Kasus Kecamatan Sumedang Utara dan Sumedang Selatan". dalam Jurnal Teknik Lingkungan Vol. 9 (2), 2008.

Purwasasmita, Mubyar. "Membangun Jawa Barat berdasarkan Pendekatan Pelestarian Lingkungan." Makalah Pelatihan Gentra Bogor. 17-11-2005.

Sobirin. 2007.

"Tragedi Kawasan Lindung dan Hilangnya Hak Azasi Alam." dalam Menyelamatkan Alam Sunda dan Kajian Lainnya Mengenai Budaya Sunda (Seri Sundalana 6). Bandung : Pusat Studi Sunda.

Widyastuti, Endang. "Permukiman Klasik di Jawa Bagian Barat (Studi Kasus: Situs Kampung Muara, Kabupaten Bogor, Jawa Barat)." dalam Prosiding Seminar Nasional Dalam Rangka 100 Tahun Purbakala. Bandung, 26-28 Agustus 2013: Balai Arkeologi Bandung.

Yondri, Lutfi. "Konstruksi dan Pola Susun Balok Batu Punden Berundak Gunung Padang - Cianjur." dalam Purbawidya Vol 2 (2) 2013.

\section{Buku}

Rosidi, Ajip. dkk. 2000.

\author{
Sosiologi Pendidikan : Isyu dan \\ Hipotesis tentang Hubungan \\ Pendidikan dengan Masyarakat. Jakarta \\ : PPLPTK Dirjen Dikti, Depdikbud.
}

Bemmelen, RW van. 1949.

The Geology of Indonesia. The Hague: Matinus Nijhoff.

Danasasmita, Saleh., Ayatrohaedi, Tien Wartini, dan Undang A. Darsa. 1987.

Sewaka Dharma, Sanghyang Siksa Kandang Karesian, Amanat Galunggung: Transkripsi dan Terjemahan. Bandung: Bagian Proyek Penelitian dan Pengkajian Kebudayaan Sunda (SUNDANOLOGI), Dirjen Kebudayaan, Departemen P dan K.

Danasasmita, Saleh. 2003.

Nyukcruk Sajarah Pakuan Pajajaran jeung Prabu Siliwangi. Bandung : Kiblat Buku Utama, 2003.

Ekadjati, Edi S. 1984.

Kebudayaan Sunda (Suatu Pendekatan Sejarah). Jakarta: Pustaka Jaya.

Goetz, JP., dan MD Lecomte. 1984.

Ethnolography and Qualitative Design in Educatiobal Research. New York: Academic Press.

Harun, Ismet B., dan Nandang Rusnandar (Penyunting). 2011.

Arsitektur Rumah dan Permukiman Tradisional di Jawa Barat, Hasil Pengamatan dan Dokumentasi. Bandung: Dinas Pariwisata dan Kebudayan Provinsi Jawa Barat.

Hermawan, Iwan. 2009.

Geografi: Sebuah Pengantar. Bandung: Private Publishing.

Lincoln, Yvonna S., and Guba, Egon G. 1985. Naturalistik Inquiry, London : SAGE Publications

Permana, R. Cecep Eka. 2006. Tata Ruang Masyarakat Baduy. Jakarta: Wedatama Widya Sastra.

Adiwikarta, Sudardja. 1988. 
Ensiklopedi Sunda. Jakarta: Pustaka Jaya.

Spreadley, James P. 2006.

Metode Etnografi (Penterjemah

Elizabeth MZ dari The Ethnographic

Interview, Ed.II). Yogyakarta: Tiara

Wacana. 